\title{
Projekty spolupráce, formy propagace: Pražský lingvistický kroužek a německojazyčný tisk v meziválečném Československu
}

\author{
Martin Bernátek
}

Pražský lingvistický kroužek (dále jako PLK nebo Kroužek) a jeho členové jsou předmětem neustálého zájmu badatelů u nás i v zahraničí (viz BOGATYREV 2011; HAVRÁNKOVÁ a PETKEVIČ 2014; JAKOBSON 2013 a SLÁDEK 2014, 2015). V posledních letech vznikly (a byly do češtiny přeloženy) souhrnné monografie o PLK, které více než ideje, koncepce a vědecké teorie spojené s Kroužkem představují dějiny společenského, politického a kulturního prostředí, ve kterých tyto koncepce vznikaly a které spolutvořily. Zejména díky monografii Jindřicha Tomana Př́běh jednoho moderního projektu (TOMAN 2011) si pod pojmem Pražský lingvistický kroužek můžeme představit soustavu vztahů mezi učenci z Brna, Bratislavy, Vídně, Ženevy či Kodaně, kteří aktivně působili v oblasti vědy a kultury meziválečné Evropy. Patrick Sériot knihou Struktura a celek (SÉRIOT 2003) rozšíril představu o východoevropských učencích spřízněných $\mathrm{s}$ Kroužkem. Znalosti o činnosti německých vědců v Kroužku a o jeho německé recepci podstatně obohatil Klaas-Hinrich Ehlers (EHLERS 2003, 2005) a nejnověji Konrad Herrmann monografií o Leopoldu Silbersteinovi (HERRMANN 2015). Tyto příspěvky spolu s monografiemi o česko-německo-ukrajinsko-ruských vztazích ${ }^{1}$ v Praze 20. a 30. let 20. století, jako např́klad publikace Oty Konráda Dějepisectví, germanistika a slavistika na Německé univerzitě v Praze 1918-1945 (KONRÁD 2011), nabízejí relativně syntetický a důkladný přehled o dějinách Kroužku, na jehož základě lze poznávat další problémy a oblasti. Tyto publikace také dnes dovolují učinit ze sumy textů, jazykovědných problémů a osobních příběhů běžně zahrnovaných pod pojem „Pražská škola“ příklad vztahů moderní vědy a kultury a prozkoumat jej na pestrém a rozporuplném kulturním a politickém pozadí meziválečného Československa.

1 Viz bibliografii v (TOMAN 2011) a (KONRÁD 2011). 
Pokud už je věnována taková nakladatelská a historiografická péče dějinám Kroužku, je dobré obrátit pozornost také k méně očividným pramenům. Při zběžném čtení Kroniky² Kroužku, která obsahuje výstřižky a materiály z let 1930-1938, mě překvapilo množství článků z deníku Prager Presse. Soubor víc než sto dvaceti uveřejněných článků o činnosti Kroužku tvoří přibližně dvě třetiny všech zde obsažených výstřižků z rozmanitých novin a časopisů. Přesto chybí ve vydané dokumentaci Kroužku (ČERMÁK, POETA a ČERMÁK 2012). Jde o cenný, ale dosud málo využitý zdroj. Německy publikované články přitom nemusí být pouze zdrojem poznání německé vědecké kultury v ČSR. Mohou poskytnout informace k celkovému studiu existence Kroužku a vědeckému provozu v meziválečném Československu.

Při práci na článku o Kroužku a Prager Presse (BERNÁTEK 2014), jehož rozšířená verze je základem předkládaného supplementa, jsem připravil anotovanou bibliografii článků o PLK uveřejněných v Prager Presse. Po doplnění přehledem článků publikovaných v odborných časopisech Slavische Rundschau, Prager Rundschau a Germanoslavica ji nyní zveřejnuji pro další badatele. Je určena hlavně historikům, lingvistům a literárním vědcům zabývajícím se Kroužkem a moderní vědou, má sloužit k chronologickému přehledu recepce PLK a také ukázat, jak členové PLK využívali těchto publikačních platforem v meziválečném Československu.

Tato periodika, která podrobněji představím níže, tvoří relativně soudržný celek. Spojuje je základní program (prezentace československé vědy v zahraničí, posilování česko-německé vzájemnosti), kulturněpolitická funkce (podpora politiky „Hradu“ a německého aktivismu) a redaktoři a přispěvatelé (Dmytro Čyževskyj, Petr Bogatyrev, Otokar Fischer, Roman Jakobson, Antonín Stanislav Mágr a další). Stranou - a výzvou pro další práci - jsem proto nechal další dobová německojazyčná periodika, zejména deník Prager Tagblatt (1877-1939). Věřím, že tento základní přehled, zaměřený na PLK, rozšíŕí představu o publikačních aktivitách jeho členů a také inspiruje další badatelky a badatele ke konkrétním analýzám a studiím o popsaných časopisech a jejich postavení v české a německé vědě a kultuře.

Vznik a zaměření periodik jako Prager Presse a Prager Rundschau bylo paradoxní: Měly zahrnout německé občany, a zejména intelektuální a kulturní elity do vytváření státu, který vznikl jako Československá republika. Používaly němčinu - středoevropskou lingua franca - ke zprostředkování domácího politického a kulturního dění svým zahraničním, převážně slovanským partnerům ČSR a tamní inteligenci. Zvýšená citlivost k jazykovým otázkám, či spíše jejich spojení s politickou situací, je patrná i v podobě používané němčiny, napřríklad užíváním varianty čechisch místo tschechisch. Jednotlivé osobnosti přispívající do těchto periodik patřily $\mathrm{k}$ různým institucím a silám v poli dobové vědě a kultury. Přehled postavení členů PLK české lingvistiky (první poloviny

2 Archiv Akademie věd $\check{C} R$, fond Pražský lingvistický kroužek (dále jako AAV PLK), inv. č. 26, kapitola VI. Knihovna, archiv. 
20. století) již shrnul Tomáš Hoskovec (HOSKOVEC 2010). Publikování článků v českém německojazyčném odborném tisku patřilo společně s ustavováním vědeckých středisek jako PLK, Slovanský ústav nebo Německá společnost pro slovanský výzkum k formám jednání k zajištění výhodného postavení v tomto poli. Konflikt PLK a časopisu Naše $\check{r} e \check{c}$ v otázce jazykového purismu, stejně jako útok Kroužku proti redaktorovi Germanoslavica Konradu Bittnerovi jsou nejznámějšími příklady takovéhoto jednání, které se uskutečňovalo v tomto symbolickém prostoru daných periodik.

Téma ohlasů Kroužku v německojazyčném československém tisku patří do dějin česko-německého soužití. Zásadní poznatky o níže představených publikačních platformách, stejně jako o podílu německých vědců na činnosti Kroužku a jeho německojazyčné recepci představil Klaas-Hinrich Ehlers (EHLERS 1997, 2001, 2002, 2003, 2005). Ve svém textu se proto omezím na základní fakta a případné zájemce o podrobnosti odkazuji na Ehlersovy studie, které jsou v českém prostředí relativně snadno dostupné. Dále se zaměřím na okolnosti česko-německého soužití a vzájemné vědecké spolupráce.

Ačkoliv k zakladatelům Kroužku patřil indogermanista Friedrich Slotty a na přednášky často docházel např́klad etnograf Edmund Schneeweis, nebyla účasti Němců v PLK věnována taková pozornost jako např. ruským emigrantům (viz EHLERS 2003: 49-52). Německé členy PLK a účastníky jeho aktivit skutečně představili Toman a hlavně Ehlers. Ten také zpochybnil představu o výhradním tradicionalismu německých vědců účastnících se aktivit Kroužku (EHLERS 2003) a doložil výrazný nárůst německých účastníků na akcích Kroužku od roku 1933 (pracoval ovšem jen s dokumenty do konce roku 1936). Ehlers také uvádí jména německých studentů navštěvujících přednášky Kroužku. Mezi německé emigranty, kteří se stali členy kroužku, patřili estetik Emil Utitz, fenomenolog Ludwig Langrebe, filosof Oskar Kraus nebo slavista Leopold Silberstein. Ten se údajně podílel také na tezích PLK z roku 1929 (HERRMANN 2014: 15) a s Klausem Mehnertem po vzoru Kroužku spoluzaložil na Berlínské univerzitě v roce 1932 slavistické pracovní sdružení (EHLERS 2005: 488, Slavistische Arbeitsgemeinschaft in Berlin 1932). Právě Silberstein, který se odborně zabýval myšlením T. G. Masaryka a novým československým státem, velmi často informoval o aktivitách Kroužku v Prager Presse. Všichni jmenovaní se také zapojili do činnosti Pražského filosofického kroužku. Známým výsledkem spolupráce obou vědeckých kolektivů pak byla přednáška Edmunda Husserla v listopadu 1935 (SILBERSTEIN 1935b), několik dní poté následovaly přednášky Silbersteina (SILBERSTEIN 1935a) a Krause (SILBERSTEIN 1935c) zaměřené na vztah filosofie a jazyka. Jak rovněž podotkl Ehlers, Kroužek mohl těmto vědcům poskytnout příležitost k inspirativní debatě, kterou patrně postrádali v provinčním a čím dál více nacionalistickém prostředí Německé univerzity v Praze (EHLERS 2003: 62).

Slavisticky zaměřená německojazyčná periodika byla přirozenou platformou bilingvních autorů jako Pavel Eisner, (českých) germanistů jako Otokar Fischer nebo Vojtěch Jirát a (německých) slavistů, např. Leopolda Silbersteina a Konrada Bittnera. Germanisté a slavisté také tvořili hlavní okruh přispěvatelů a čtenářů odborných časopisů jako Germanoslavica a Slavische Rundschau. Ačkoliv se podoba a průběh této spolupráce v jednotlivých periodicích lišily, v celku korespondovaly s politickým vývojem česko-německých vztahů během 20. a 30. let minulého století. Programové a kolektivní práce, 
konfrontace s jinými disciplínami a účast v aktuálním společenském dění patřily k dobovému étosu moderní vzdělanosti, jak jej formuloval např́íklad Vilém Mathesius v souboru úvah Kulturni aktivismus, a zejména v textu „Česká věda“ (MATHESIUS 1925). Po vzoru Kroužku v Praze vznikly další vědecké kolektivy a jejich aktéři se potkávali na akcích PLK nebo v redakcích zde popsaných periodik. Pomyslnou osu jejich vývoje tvoří východiska v programové spolupráci, politická polarizace a kolaps programu česko-německé spolupráce.

\section{Prager Presse: Veřejná kronika Kroužku}

Německojazyčný deník Prager Presse (1921-1938) v březnu 1921 založila a financovala zpravodajská sekce československého ministerstva zahraničních věcí. V roce 1922 převzalo jeho vydávání státní nakladatelství Orbis (DEJMEK 2012: 37). Vedoucím a tváří Prager Presse byl šéfredaktor Arne Laurin, energický novinář, který udržoval kontakty s většinou významných představitelů československého státu i tehdejší kultury (ŠTEFANOVÁ 2009: 65). Jeho zástupcem a redaktorem kulturní rubriky byl Antonín Stanislav Mágr. Deník vznikl z popudu prezidenta Masaryka (MÁGR 1947: 8) a zastával oficiální „hradní“ politickou linii. Sloužil zahraniční prezentaci Československa, ale také zprostředkovával zprávy a posiloval vzájemné vztahy - byt německy - hlavně mezi slovanskými státy střední Evropy. Podle Barbary Köpplové domácí němečtí čtenáři noviny bojkotovali a jejich náklad nedosáhl předpokládané výše (KÖPPLOVÁ 1986: 12, 16). V březnu 1937 měl deník celkem 4426 abonentů z celého světa a z toho v ČSR celkem 2 423. ${ }^{3}$ Měl relativně malý náklad, ale mezi jeho čtenáře patřila hlavně kulturní a společenská elita. ${ }^{4}$ Prager Presse zřejmě nechyběl v žádné solidní středoevropské kavárně. Jak poznamenal Roman Ingarden v dopise Mágrovi: ve Lvově jsou nová čísla k dostání v několika kavárnách. ${ }^{5}$ Spolu s rozpadem Masarykovy a Benešovy politické koncepce zanikl po Mnichovu i deník Prager Presse (stejně jako Slavische Rundschau a Prager Rundschau). Po emigraci šéfredaktora Laurina do USA vedl časopis od 15. listopadu 1938 do jeho likvidace v lednu 1939 právě Mágr. Poslední číslo deníku vyšlo na Silvestra 1938.

Kulturní rubriku, která v době 1. 4.1925 - 1. 7. 1932 vycházela pod názvem „Kultur der Gegenwart“ a později jako „Kulturchronik“ (MÁGR 1946: 8), redigoval Mágr spolu s básníkem a překladatelem Otto Pickem. Literaturu měl na starosti básník, překladatel a člen PLK Pavel Eisner, divadlu se věnoval romanista a teatrolog Václav Tille a Antonín Stanislav Mágr měl na starosti hlavně vědu a slavica. Zejména články se slavistickými tématy do Prager Presse přispívali členové Kroužku Petr Bogatyrev, Otokar Fischer,

3 Literárni archiv Památníku národního písemnictví, fond Mágr, Antonín Stanislav (dále jako PNP Mágr), inv. č. 1027, karton 1 - doklady vlastní, Prager Presse - konvolut materiálů ke kulturní rubrice, Počet abonentů k 21. 3. 1937.

4 PNP Mágr, karton 1 - doklady vlastní, Prager Presse - opisy posudků a hodnocení Prager Presse z let 1927-1937.

$5 \quad$ PNP Mágr, karton 3, korespondence přijatá. Ingarden Roman, 12. 5. 1936. 
Roman Jakobson, Sergej Karcevskij, Petr Savickij, Miloš Weingart nebo Frank Wollman. Př́ležitostně zde publikoval také Jan Mukařovský a další členové Kroužku jako Leopold Silberstein, Emil Utitz nebo Karel Kožešník. Mezi přátele a spolupracovníky z kulturních kruhů v roce 1936 Mágr počítal také filosofy Oskara Krause a Emanuela Rádla, za potenciální přispěvatele považoval režiséry E. F. Buriana a Jaroslava Kvapila nebo hereckou dvojici Jiř́ího Voskovce a Jana Wericha. ${ }^{6}$

Redaktoři Prager Presse Jaromír Pečírka a František Kubka patřili podobně jako Savickij, Trubeckoj a Jakobson ke stoupencům eurasijství. Základem této geopolitické a kulturní koncepce a ideologie, rozšriřené hlavně mezi ruskými emigranty mezi válkami, je představa svébytnosti prostoru mezi střední Evropou a Pacifikem - Eurasie - , který je určen spojením tatarských a východoslovanských kultur a odlišuje se od západní kultury (komplexně viz SÉRIOT 2003). Kunsthistorik Pečírka pomáhal formulovat program výtvarné, v souladu s eurasijskou koncepcí působící skupiny Skytové (Skify), kterou tvořili ukrajinští a ruští výtvarníci sdružení kolem malîře Sergeje Maka. Společně s Kubkou Skify propagovali na stránkách v Prager Presse (HAUSER 2009).

V Prager Presse již během dvacátých let vycházely články o tehdejš́ jazykovědě a zprostředkovávaly zejména výzkumy Miloše Weingarta. ${ }^{7}$ Texty o německé literatuře, literárněvědnými úvahami a př́ležitostně také básněmi zde také přispíval Otokar Fischer. Zřejmě poprvé je Kroužek v Prager Presse zmiňován v souvislosti s I. sjezdem slovanských filologů v Praze na podzim roku 1929. Deník zde uveřejnil zprávu (Moderne Sprachwissenschaft und Slavistik 1929: 8) o razantním vystoupení členů Kroužku v lingvistické sekci, kteří „ve svých devíti tezích předložili tak bohatý materiál, že by k jeho prodebatování byl potřeba malý speciální sjezd“. ${ }^{8}$ Byly zde také shrnuty jednotlivé teze. Spolu s dalšími zprávami o sjezdu v Prager Presse vyšel také překlad Jakobsonova článku „Romantické všeslovanství - nová slavistika“ pro časopis Čin (MÁGR 1929c; JAKOBSON 1929), ve kterém jsou ale vynechány pasáže představující strukturální lingvistku, pojem „strukturalismus“ a PLK. Během následující dekády deník Prager Presse zveřejnil velké množství zpráv z domácích či zahraničních vědeckých kongresů, kterých se účastnili členové Kroužku. Mathesius zde informoval o Kroužkem pořádané mezinárodní fonologické konferenci v Praze, o „intenzivní koncentraci“ (MATHESIUS 1930) během tohoto setkání a přípravě na mezinárodní sjezd lingvistů v Ženevě. Necelý rok poté jej čtenářům Prager Presse popsal Jakobson (JAKOBSON 1931a). V Prager Presse vyšly Jakobsonovy medailonky jazykovědců a kolegů Friedricha Slottyho (JAKOBSON 1931b), Viléma Mathesia (JAKOBSON 1932b), Františka Trávníčka (JAKOBSON 1938), Olafa Brocha (JAKOBSON

$6 \quad$ PNP Mágr, karton 1 - doklady vlastní: Prager Presse - seznam spolupracovníků z kulturních okruhů $\mathrm{z}$ roku1936.

7 Viz např. zprávu o Weingartových přednáškách z roku 1925, vydaných v ročence Komenského univerzity (Die slavische Wechselseitigkeit in Vergangenheit und Gegenwart 1926: 6).

8 „Der Zirkel, eine freie Arbeitsgemeinschaft, die es sich zur Aufgabe gemacht hat, die Ergebnisse der neuen Sprachwissenschaft zu verfolgen, aktiv an ihrer Weiterbildung zu arbeiten und sie für die einheimische wissenschaftliche Tätigkeit fruchtbar zu machen, legt in den neun ,Thesen' eine solche Fülle von Material vor, daß eigentlich ein kleiner Spezialkongreß vonnöten wäre, um es durchzudebattieren." (Moderne Sprachwissenschaft und Slavistik 1929: 8) 
1937b) nebo Eisnerův nekrolog Nikolaje Trubeckého (EISNER 1938). V nedělní příloze Prager Presse byla otištěna část Bogatyrevovy a Jakobsonovy studie „Folklor jako zvláštní forma tvorby“ (BOGATYREV a JAKOBSON 1929: I-III). Eisner v Prager Presse zveřejnil například shrnutí studie Ingeborg Seidlové-Slottyové o vlivu národního socialismu na německý jazyk, která vyšla ve Slově a slovesnosti (EISNER 1936) nebo recenzoval sborník Spisovná čeština a jazyková kultura (EISNER 1932). Stejnojmennému přednáškovému cyklu a diskusi o jazykovém brusičství se v několika příspěvcích věnoval Mágr (viz MÁGR 1932a, 1932b, 1932c, 1932e, 1932f, 1932g, 1932h), který také diskusi vnímal v souvislosti s pojetím duchovní krize společnosti u Karla Jasperse (MÁGR 1932e).

Pro poznání historie Kroužku jsou podstatné články shrnující jednotlivé přednášky. Za zmínku stojí relativně neznámé články Romana Jakobsona o přednáškách Alfréda Béma (JAKOBSON 1932a: 7) a Vigga Brøndala (JAKOBSON 1935: 6) nebo článek o kritické přednášce René Welleka o Teorii prózy Viktora Šklovského (KOŽEŠNíK 1934: 6). Představují v podstatě veřejnou kroniku Kroužku a významný pramen poznání hlavně pro období do roku 1935, kdy začala ve Slově a slovesnosti vycházet shrnutí přednášek. Na rozdíl od těchto textů, které redakci často poskytovali sami autoři, ${ }^{9}$ vycházely v Prager Presse zprávy přímých účastníků. Umožňují proto přehled nejen o výkladu přednášejícího, ale také o tématech probíraných v diskusi. Např́iklad Mathesiovy přednášky „O požadavku stability spisovné češtiny“ se v lednu 1932 účastnil tehdejší hlavní protivník Kroužku, představitel doktríny jazykového purismu a šéfredaktor časopisu Naše řě Jiří Haller. Podle Mágra se Haller nedokázal v diskusi bránit proti výhradám členů Kroužku a obhájit své stanovisko dostatečnými argumenty (MÁGR 1932a).

Ve většině článků nechybí informace o diskusích a diskutujících a jednoznačně mezi nimi dominuje jméno Romana Jakobsona. Ze souboru článků v Prager Presse se lze dozvědět o chystaných, ale neuskutečněných aktivitách. Umožňují také čerpat nové informace o přednáškách zahraničních hostů v Kroužku, kteří vystoupili vedle PLK v dalších pražských či českých institucích. Například Olaf Broch přednášel v roce 1938 kromě v PLK také na Filozofických fakultách Karlovy univerzity a Masarykovy univerzity (Zum Ostnorwegischen 1938: 8). Louis Hjelmslev přednášel (francouzsky) pro PLK v kavárně Zlatá husa v říjnu 1937 a dále (česky) jako host Ústavu skandinávského a nizozemského několik dní dříve ve Společenském klubu Na Příkopě (JAKOBSON 1937c: 8). Přednáška muzikologa Gustava Beckinga „Hudební dílo jako znak“ se uskutečnila v Ústavu hudební vědy Filozofické fakulty Německé univerzity v Praze (HEXTER 1935: 7). Přednášky v Kroužku nebyly v některých případech omezeny jen na vědecký výklad, ale byly doplněny i ukázkami. Například Mihajlo Rostohar 14. března 1932 rozšíŕil svou přednášku o vztazích strukturální jazykovědy a psychologie o akustické experimenty (Die Sprachlaute im Lichte der Psychologie 1932: 10). Slavnostní zasedání Kroužku u příležitosti stého narození básníka Vítězslava Hálka a Mukařov-

9 Např́klad Bogatyrev upravil v pozdějším vydání článku o přednášce Alexandra Koyrého v Prager Presse v Souvislostech tvorby (BOGATYREV 1971: 55-57, původní verze BOGATYREV 1930b) části odkazující k události přednášky. Tím ale znejasnil rozlišení mezi svým komentářem a Koyrého myšlenkami. 
ského přednášku o Hálkovi uzavřel 8. dubna 1935 recitací Hálkových básní herec a básníkův vzdálený př́ibuzný Zdeněk Štěpánek.

Zpráva o plánu činnosti Kroužku na rok 1932/1933, otištěná v Prager Presse, obsahuje zmínku (Der „Pražský linguistický kroužek“ 1932: 8) o Jakobsonově chystané přednášce o šlágrech Jiř́ího Voskovce a Jana Wericha, která se ovšem nikdy neuskutečnila. Jakobson kolem roku 1932 zamýšlel napsat na toto téma monografii, ale ani tento záměr se neuskutečnil a zveřejněny byly jen jeho poznámky k tématu (JAKOBSON 1933). Podle těchto informací soudím, že Jakobsonův zájem o poetiku této herecké dvojice, který je známý hlavně z jeho článku „Dopis Voskovci a Werichovi o noetice a sémantice švandy“ z roku 1937 (JAKOBSON 1937a), má dávněǰší kořeny. Na základě zprávy z Prager Presse považuji přednášku Františka Trávníčka o české výslovnosti z 13. května 1935 za první soustavnější pojednání o divadelním tématu v rámci Kroužku. Trávníček mluvil o své publikaci Správná česká výslovnost, kterou vydalo Zemské divadlo v Brně. Na rozdíl od čistě jazykovědně zaměřené publikace (TRÁVNÍČEK 1935) se v přednášce zabýval problematikou jevištní češtiny a její výslovnosti z hlediska funkčnosti a charakterizace postavy. Trávníček se také zmínil o výslovnosti ve filmu a rozhlase, otázkách normování výslovnosti a jejího systematického výzkumu právě v oblastech divadla, filmu a rozhlasu.

\section{Redaktor Mágr a vědecká žurnalistika}

Soubor článků o PLK v Prager Presse zdaleka přesahuje množství textů zveřejněných v jiných tehdejších periodikách. Na rozsáhlé publicitě měl zásadní podíl redaktor Mágr (1887-1960). Tento novinář, slavista a př́ležitostný překladatel, původem Čech, který žil do začátku 20. let v Lipsku, se stal stálým redaktorem deníku 1. 3. 1923 a zůstal jím až do jeho úplného konce v lednu 1939. V březnu 1929 byl jmenován činným členem Slovanského ústavu v kulturním (I.) odboru ${ }^{10}$ a aktivně se podílel na činnosti zpravodajského odboru I. sjezdu slovanských filologů v Praze 1929, ${ }^{11} \mathrm{kde}$ mj. členové Kroužku vystoupili se svými slavnými Tezemi. Patřil k spoluzakladatelům odborných časopisů Slavische Rundschau a Germanoslavica a působil jako technický redaktor Prager Rundschau..$^{12}$ Mágrova spřízněnost $\mathrm{s}$ Kroužkem rozhodně přesahovala meze běžné spřízněnosti novináře $\mathrm{s}$ předmětem jeho zájmu. Mágr patřil $\mathrm{k}$ stálým hostům navštěvujícím přednášky PLK. Jako první lze doložit jeho účast na přednášce PLK 4. 5. 1931, kdy přednášel Otokar Fischer o Konrádu Wallenrodovi (ČERMÁK, POETA a ČERMÁK 2012: 116). O jeho zájmu o činnost Kroužku svědčí také korespondence s Bohumilem

10 PNP Mágr, karton 1 - doklady vlastní, jmenování A. S. Mágra činným členem Slovanského ústavu 28. 3. 1929 .

11 PNP Mágr, karton 1 - doklady vlastní, Prager Presse - konvolut materiálů ke kulturní rubrice. I. sjezd slovanských filologů v Praze.

12 PNP Mágr, karton 7 - rukopisy vlastní: Materiál k životopisu samouka-slavisty a novináře sestavený pro dějiny české slavistiky chystané Slovanským ústavem v Praze. 
Trnkou ${ }^{13}$ Frankem Wollmanem ${ }^{14}$ nebo Bohuslavem Havránkem. ${ }^{15}$ Aktivně se Mágr do činnosti Kroužku zapojoval jen výjimečně, například tehdy, když společně s Pavlem Eisnerem na schůzi Kroužku 27. ledna 1936 hodnotili první ročník Slova a slovesnosti. Mágr se o svém poměru ke Kroužku vyjádřil následovně: „Stojím mimo Pr. ling. kroužek, nejsem odborníkem ani v linguistice ani v literární vědě a mohu se dívat na vaši literární práci [tj. Slovo a slovesnost] jen jak obyčejný čtenář a ovšem jako novinář, který sleduje proudy a směry současného dění kulturního a pokouší se o kritické zhodnocení jaksi všeobecné." (MÁGR 1936: 132) Zprávu o polské recepci ruského formalismu, o kterou byl Mathesiem žádán do kroniky Slova a slovesnosti, zřejmě pro velkou zaneprázdněnost nenapsal, ani zde nepřispěl ničím jiným. ${ }^{16}$

Nejtěsnější vazby s Mágrem pravděpodobně udržoval ze členů Kroužku jeho redakční kolega z Prager Presse Eisner a ze Slavische Rundschau Jakobson. Na základě několika dopisů z Mágrovy korespondence lze také doložit Jakobsonovu úlohu prostředníka mezi Mágrem a dalšími členy Kroužku. ${ }^{17}$

Mágrova relativně usilovná a soustavná propagace aktivit Kroužku vycházela z jeho zaujetí pro slovanskou kulturu a z citlivosti $\mathrm{k}$ aktuálním problémům tehdejší vědy. Podle Eisnera byl redaktor Mágr „nádherný nemluva a neruda, postrach galantních návštěv redakčních, ale vtělený klid, řád, kázeň, dochvilnost“ (EISNER 1937:16). V kulturní rubrice Prager Presse vytvořil oddíl s texty, ,jimž vědecká přesnost, rozhled a podnětný duch redaktorův dodává ceny trvalé“ (HORÁK 1937: 5).

Mágr nebyl publicista otevírající zásadní pohled na díla a problémy podrobným rozborem či novou interpretací. Šlo mu o zprostředkování toho nejlepšího a nejpodstatnějšího nejen z československé kultury.

Mágrovy padesáté narozeniny (6. 4. 1937), ke kterým mu byl věnovaný sborník připravený redakčním kolegou z Prager Rundschau Antonínem Hartlem (HARTL 1937a), se staly příležitostí k zhodnocení významu kulturní rubriky Prager Presse a k úvahám o vztahu žurnalistiky a vědy. Podle Havránka „nebylo u nás dosud listu, jehož kulturní rubrika by se dala zdaleka srovnávati s kulturní částí Prager Presse. " ${ }^{18}$ Mukařovský ve svém př́spěvku kritizuje nezájem vědců o popularizaci vědy, který je způsobený hledáním vlastní svébytnosti a snahou o uplatnění v mezinárodním akademickém dění: „Učencủm zdá se naléhavější vědecké hodnoty tvořit, než vytvořené, po případě přejaté, činit stravitelněǰšími laickému publiku.“ (MUKAŘOVSKÝ 1937b: 23) Konstatuje ale, že „naopak věda a široká veřejnost se [v druhé polovině 30 . let] přibližují. Nejde přitom o výklad obecně uznaných pravd,

13 AAV PLK, karton 2 - inv. č. 18, kapitola III, oddíl e - Korespondence se členy a spolupracovníky. Složka Mágr.

14 PNP Mágr, karton 5 - korespondence přijatá, Wollman Frank, 10. 4. 1937.

15 PNP Mágr, karton 3 - korespondence přijatá, Havránek Bohuslav, 5. 4. 1937 a 10. 1. 1939.

16 PNP Mágr, karton 3 - korespondence přijatá, Mathesius Vilém, 3. 12. 1935.

17 PNP Mágr, karton 3 - korespondence přijatá, Trnka Bohumil, 22. 11. 1932; PNP Mágr, karton 5 - korespondence přijatá, Wollman Frank, 10. 4. 1937.

18 PNP Mágr, karton 3 - korespondence přijatá, Havránek Bohuslav, 5. 4. 1937. 
ale o přiblížení boje o nové pravdy a hodnoty a sledování vědecké práce v samém zrodu.“ (MUKAŘOVSKÝ 1937b: 23) Publikum si dle Mukařovského nežádá, ,aby věda sestupovala $\mathrm{k}$ němu, ale žádá si vzestoupit samo k vědě“ (MUKAŘOVSKÝ 1937b: 23). „Úkol vědeckého žurnalisty je dvojstranný: orientuje publikum v bludišti vědeckého zkoumání a získává, z druhé strany, oporu veřejného mínění tomu, co je ve vědě živé.“ (MUKAŘOVSKÝ 1937b: 24) Pro Mukařovského pak Mágr představuje klasický typ či dokonalý obraz vědeckého žurnalisty (MUKAŘOVSKÝ 1937b: 24).

Jakobson jde ve svém článku v Lidových novinách (JAKOBSON 1937d: 9), který měl původně vyjít ve sborníku pro Mágra (ale byl mu vrácen $\mathrm{s}$ „doprovodem doopravdy podivným a trapným“"), ${ }^{19}$ ještě dál: tisk nemá jen popularizovat vědu, ale být i diskusní tribunou jejich aktuálních témat: „Kde jde o důrazné zahrocení otázky, o vymezení hesel, o rázné upozornění na akutní kulturní nebezpečí, o sepětí teorie s praksí, tam se právě hlavně uplatňují specifické vlastnosti novin." Spíš než nezájem vědců o popularizaci své práce na veřejnosti kritizuje oboustranné nebezpečí jejich oddělování. Rozmanitý záběr novin je mu protiváhou úzké specializace vědy. Jakobson též zdůrazňuje, že pojem současnosti a současného bádání zahrnuje také poměr současnosti k minulosti a náš vztah $\mathrm{k}$ dnešním záležitostem je stejně aktuální jako náš vztah $\mathrm{k}$ minulosti: „Věda je stejně časově zapojena jako politika a tato časovost se bezděky jeví ve volbě a filtraci témat a především v zorném úhlu“, a proto i pro novináře platí požadavek vědeckosti. Mágr je pak dle Jakobsona jedním z mála, který toto vše chápe a důsledně naplňuje. Jakobsonovy a Mukařovského úvahy lze také chápat jako zobecnění praxe čtvrtletníku Slovo a slovesnost, jehož prostřednictvím Kroužek usiloval o propojení lingvistiky a literární vědy se sousedními obory i s kulturní praxí. ${ }^{20}$ Podle Jakobsona „málokdo pochopil a zhodnotil tak záhy a tak plně jako Vy naše úsilí, plány, boj a nesnáze a málokdo šel s námi tak společnou cestou. "21 Že tato potřeba nebyla pocitována všemi členy v Kroužku, dokumentuje korespondence Jakobsona s Nikolajem Trubeckým. Trubeckoj vytýkal Jakobsonovi, že se zaplétá s „žurnalismem“ (JAKOBSON 1975: 313, 327).

Kroužek měl být Mágrovi rozhodně za co vděčný. Jeho jednotliví členové měli jedinečnou př́ležitost utvářet zde vlastní „public relations“ a podporovat linii zastávanou Kroužkem, at už šlo o vzájemné recenze publikací (viz KARCEVSKIJ 1930; JAKOBSON 1936) nebo o Mágrovy příspěvky z období boje proti jazykovému brusičství časopisu Naše řě v roce 1932 (MÁGR 1932a, 1932b, 1932c, 1932e, 1932f, 1932g, 1932h). Představitelé Kroužku mohli prostřednictvím Prager Presse a jeho hlavních redaktorů udržovat kontakty s „prohradním“ kř́́dlem české politiky či s mecenáši, jak tomu zřejmě bylo v př́ípadě vztahu avantgardního režiséra Jiř́ího Frejky a šéfredaktora Laurina. Bylo výhodné držet se Prager Presse (RAUCHOVÁ 2009: 214-215).

Domnívám se, že toto spojenectví s Prager Presse patřilo k důležitým strategiím v prosazení se aktérů Kroužku a rozš̌iření jejich myšlenek na poli meziválečné vědy, podobně

19 PNP Mágr, karton 3 - korespondence přijatá, Jakobson Roman, 5. 4. 1937.

20 Viz Propagační leták Slovo a slovesnost [1935?] (AAV PLK - inv. č. 26, Kapitola VI. Knihovna, archiv).

21 PNP Mágr, karton 3 - korespondence přijatá, Jakobson Roman, 5. 4. 1937. 
jako bylo důležité vydávání Slova a slovesnosti nebo kolektivní vystupování Kroužku a jeho spolupráce s dalšími vědeckými spolky. Prager Presse je př́íladem intenzivní propagace myšlenek moderní vědy - a v př́padě Kroužku strukturální lingvistiky - ve veřejném životě. Na tomto základě si lze uvědomit, jak bylo pro PLK podstatné propojit vědu s životem a s aktuálními dobovými problémy. Ostatně s těmito záměry vznikal časopis Slovo a slovesnost a v tomto duchu členové Kroužku psali o Mágrově novinářské práci.

\section{Slavische Rundschau}

Revue Slavische Rundschau (1929-1940) měla být prostředkem modernizace slavistiky. Tato změna měla podle redaktorů časopisu spočívat v odklonu od ryze filologické orientace oboru, $\mathrm{v}$ jeho kombinaci s dějepisem a vést ke koncepci slovanských kulturních studií. Součástí tohoto záměru byla také popularizace slavistického bádání a kolektivní způsob práce (GESEMANN 1929; KONRÁD 2011: 182-190). Časopis se měl „pohotově, spolehlivě a kriticky“ zabývat aktuálním stavem celého moderního kulturního života slovanských národů a spojovat jej s evropským kontextem (Eine neue slavistische Revue 1928). Proto hodlali redaktoři spolupracovat s pedagogy a umělci. Vedle vědců měl být nový časopis určený také politikům, podnikatelům a diplomatům. Redakce v propagační brožuře ohlašovala kromě literárních témat také články o kinematografii, problémech české muzikologie nebo o divadle v Záhřebu. V avizovaném seznamu spolupracovníků byli uvedeni mimo jiné Roman Ingarden, Gustav Špet, Boris Tomaševskij, Hubert Ripka, Ilja Ehrenburg nebo Karel Teige (Slavische Rundschau 1929). Nová slavistická platforma byla připravována od konce roku 1927 (EHLERS 1997: 69-70) Mágrem a německými slavisty Franzem Spinou a Gerhardem Gesemannem. Mágr v souvislosti se založením nového časopisu zmiňuje také své kontakty s Milošem Weingartem, Schneeweisem a Jakobsonem. ${ }^{22}$ Jejich společným výsledkem byl časopis Slavische Rundschau, vydávaný v prestižním berlínském vědeckém nakladatelství Walter de Gruyter, jehož první číslo mělo vyjít v záŕí 1928, ale nakonec vyšlo jako dvojčíslo v únoru 1929 (Eine neue slavistische Revue 1928), a od roku 1931 také čtvrtletník Germanoslavica. Ehlers upozorňuje na původní program časopisu, který byl podobně jako Germanoslavica, Prager Rundschau a Prager Presse založený na německo-slovanské vzájemnosti a na propojování vědeckých článků slavistických, etnografických a literárněhistorických s publicistikou z rozmanitých oblastí kulturního života Slovanů (EHLERS 1997: 152-153). Franz Spina (1868-1938), od roku 1921 řádný profesor českého jazyka na Německé univerzitě v Praze, tento program zosobňoval nejen ve vědě, ale i v politice. Jako představitel německého politického aktivismu a předseda Německého svazu zemědělců (Bund der Landwirte) prosazoval státotvornou politiku sudetoněmeckých stran a v letech 1926-1936 zastával také různé ministerské pozice (KONRÁD 2011: 181).

Gesemann a Spina zakládají v roce 1930 po vzoru PLK a Moskevského lingvistického kroužku Německou společnost pro slovanský výzkum (Deutsche Gesellschaft für

22 PNP Mágr, karton 3 - korespondence přijatá, Havránek Bohuslav, 9. 12. 1927. 
slavistische Forschung) (GESEMANN 1930; EHLERS 1997: 176), která je zodpovědná za další vydávání obou periodik. Strukturu čísla tvořily studie, recenze uspořádané dle jednotlivých jazyků, bibliografický a kulturní přehled a nekrology. V bibliografické rubrice se od sedmého ročníku Slavische Rundschau (1936) objevuje nepravidelně přehled článků publikovaných v číslech Slova a slovesnosti. Mágr měl na starosti polskou sekci, ${ }^{23}$ Jakobson zodpovídal dlouhou dobu za východoslovanskou sekci. Spolu s nimi redakci tvořili slavisté Joža Glonar, Eugen Rippl, Schneeweis a lektorka polštiny Iza Šaunová. Od druhého ročníku přibyli do redakce Maxim Hekter a Ferdinand Liewehr, odešel Schneeweis. Publikovali zde členové PLK Bogatyrev, Bém, Čyževskyj, Nikolaj Durnovo, Eisner, Fischer, Gesemann, Havránek, Jirát, Jakobson, Karcevskij, Mathesius, Mukařovský, Rippl, Savickij, Silberstein, Utitz a Wollman. Členové PLK Jakobson, Rippl a Ferdinand Liewehr přispěli do Liewehrem redigovaného speciálního sborníku Slavistische Studien (LIEWEHR 1929), který věnovali Spinovi jeho žáci. Když Slavische Rundschau vydalo na konci roku 1938 speciální číslo o starší duchovní historii západních Slovanů, věnované památce zemřelého redaktora Spiny, nechyběly zde studie van Wijka, Jakobsona, Hrabáka, Trávníčka, Havránka, Bogatyreva, Jiráta a Weingarta (který již nebyl členem PLK) a pozdějšího člena Kroužku Jozefa Růžičky.

Po celou dobu existence Slavische Rundchau zde vycházely zprávy o Kroužku (např. MATHESIUS 1933; HAVRÁNEK 1936). Podle jeho vzoru údajně vznikl vedle Německé společnosti pro slovanský výzkum také Etnografický kroužek, jehož iniciátorem byl Bogatyrev (Ein „Ethnographischer Zirkel“ 1930, viz též EHLERS 2011: 26-28). Vyšly zde také některé Bogatyrevovy důležité studie, např́ílad „Etnografická praxe“, kde popsal své zkušenosti ze sběru etnografických fakt na Podkarpatské Rusi (BOGATYREV 1930a) nebo „K otázce společných uměleckých postupů v staročeském a lidovém divadle“ (BOGATYREV 1838).

Časopis se snažil udržet zdání neutrality, od počátku byl ale nevyhnutelně svázán s národnostní problematikou v ČSR. Jak podotýká Ehlers, časopis byl z české strany - redaktorem Slovanského prèhledu Antonínem Frintou - kritizovaný za ambice „pomocí ,německého kulturního prostředí zprostředkovat cestu Slovanům do Evropy“ (EHLERS 1997: 174). Z německé strany, konkrétně např. historikem a členem Sudetoněmecké strany Josefem Pfitznerem, byl časopis odmítán jako bytostně cizí, neněmecký a vedený Židy (KONRÁD 2011: 183). Gesemann, který byl zvolený rektorem Německé univerzity v Praze pro akademický rok 1933/1934, se v této době stal členem Sudetoněmecké strany a odklonil se od Spinova programu, ačkoliv byl svými nepřáteli stále kritizován za aktivistickou orientaci (KONRÁD 2011: 71). Gesemann také demonstrativně odmítl účast na setkání rektorů československých vysokých škol na jaře 1934 (KONRÁD 2011: 70). Poslední číslo Slavische Runschau vychází už během německé okupace v roce 1940. Gesemann ještě krátce působil v čele Slovanského ústavu, který byl v roce 1943 začleněn do Řǐšské Nadace Reinharda Heydricha pro vědecká bádání v Praze (Reinhard Heydrichs Reichstiftung für wissenschaftliche Forschung in Prag) (ROUBÍK 1947-1948). 


\section{Germanoslavica}

Z iniciativy českých germanistů a německých slavistů a z představ o česko-německé spolupráci v oblasti vědy a kultury vznikl také čtvrtletník pro výzkum německo-slovanských kulturních vztahů Germanoslavica, který v letech 1931-1937 vycházel v nakladatelství Rudolf M. Rohrer (EHLERS 2005: 457-489). Časopis Germanoslavica (stejně jako Slavische Rundschau společně vydávaly Slovanský ústav a Německá společnost pro slavistický výzkum v Praze. Podnět k založení časopisu podali na Ministerstvo školství a národní osvěty v březnu 1930 němečtí slavisté Spina a Gesemann, germanista Fischer a Mágr (EHLERS 2001: 87). Iniciátoři se také odvolávali na závěry I. sjezdu slovanských filologů v Praze roce 1929 (EHLERS 2001: 87). Hlavními redaktory Germanoslavica byli Spina a český germanista Josef Janko, redakčními tajemníky germanista Vojtěch Jirát a germanoslavista Konrád Bittner. Časopis Germanoslavica měl být, stejně jako všechna popsaná periodika, prostředkem pokojného soužití Němců a Čechů ve společném státě (EHLERS 2001: 85-86, 98).

Koncepcí i obsazením redakce odpovídal časopis dobovým diskusím o ustavení nového oboru germánsko-slovanských studií (EHLERS 2001: 83-103; FISCHER 1929 a GESEMANN 1929). Bittner se také stal v roce 1930 prvním (soukromým) docentem tohoto oboru na Německé univerzitě v Praze (KONRÁD 2011: 180). Účelem této nové vědecké platformy bylo

prozkoumat a představit germánsko-slovanské kulturní vztahy v průběhu dějin na co nejširší základně: předmětem zájmu jsou také politické, hospodářské a právní dějiny, dějiny jazyka, literatury a filozofie, dějiny výtvarného umění a hudby, srovnávací národopis, do té míry, pokud ve všech těchto oblastech nalézáme živoucí vzájemné vztahy, duchovní obohacení a jejich vliv. (KONRÁD 2011 dle Zum Geleit 1931)

Mágr upozornil na souvislost s časopisem pro studium byzantsko-slovanských vztahů Byzantinoslavica, který Slovanský ústav začal vydávat v roce 1929 a v Prager Presse opakovaně formuloval potřebu publikační platformy pro studium německo-slovanských vztahů (MÁGR 1929a, 1929b). Germanoslavica byla z titulu především platformou slavistů a germanistů: opakovaně zde publikovali (budoucí) členové Kroužku Alfréd Bém, Vojtěch Jirát, Otokar Fischer a Dmytro Čyževskyj, který svými články o A S. Puškinovi „ovládl“ poslední číslo (ř́ijen 1937) sedmi příspěvky (viz např. ČYŽEVS'KYJ 1937). Několika články zde přispěli Eugen Rippl a Leopold Silberstein, studii o paralelách mezi indogermánskými a baltoslovanskými jazykovými rodinami a skupinami zde otiskl Nicolaas van Wijk (WIJK 1935). Vyšla zde Bogatyrevova studie o funkční proměně etnografických faktů „Vánoční stromek na východním Slovensku“ (BOGATYREV 1932) nebo Fischerova přednáška o poemě Adama Mickiewicze Konrád Wallenrod, původně přednesená (4. 5. 1931) v PLK (FISCHER 1931-1932). Jinak byl vztah ke Kroužku a jeho prosazované metodě omezený na ojedinělé citace či odkazy. 
Časopis, který vznikl v době silících účinků hospodářské krize, se od počátku potýkal s finančními problémy. Skutečné subvence byly nižší než slíbená podpora a vyhlídky na zlepšení finanční situace ještě během vydávání prvního ročníku na začátku roku 1932 vystřídalo další zhoršení financování. Klaas-Hinrich Ehler mluví doslova o agonii (EHLERS 2002: 183). Žalostný nedostatek prostředků vedl k mezeře ve vydávání časopisu: po čtvrtém čísle druhého ročníku (1932/1933) následovalo další číslo až v roce 1935. S hospodářskou krizí na počátku 30. let minulého století se časopis, který vycházel díky podpoře Ministerstva školství a národní osvěty, státem zřízeného Slovanského ústavu a Německé společnosti pro Vědu a umění Československé republiky (Deutsche Gesellschaft der Wissenschaften und Künste für die Tschechoslovakische Republik) a jehož roční předplatné stálo 160 Kč, dostal do vážných problémů. Politická radikalizace sudetských Němců, vyvolaná nástupem nacizmu v sousedním Německu, a separatistická politika Sudetoněmecké strany vedly ke ztrátě voličů aktivistických stran a kolapsu Spinova programu česko-německé spolupráce. Kritickým momentem tohoto období, vedoucím následně k rozpadu redakce Germanoslavica, byla kritika Bittnerovy knihy Deutsche und Tschechem (1936) a kampaň proti Bittnerovi samotnému. Už v lednu 1936 byly ve výboru Slovanského ústavu vyslovovány námitky „proti neslovanské tendenci některých př́spěvků ve sborníku Germanoslavica“ (EHLERS 2002: 191). Kroužek, a zejména Frank Wollman, odsoudil knihu pro politickou instrumentalizaci dějin (EHLERS 2002: 193-196). Členové PLK také usilovali o odstranění Bittnera z redakce Germanoslavica, ačkoliv jeho redakční kolega a člen Kroužku Jirát, podobně jako jeho další člen a profesor slavistiky na Německé univerzitě v Praze Rippl, zastávali ke knize a Bittnerovi mírnější postoj než PLK (viz RIPPL 1936). Bittner, od listopadu 1937 člen Sudetoněmecké strany, pod tímto nátlakem opustil redakci Germanoslavica, čímž ještě více destabilizoval vydávání časopisu a poslední dvojčíslo pátého ročníku tak dokončil na jaře 1938 Jirát sám (EHLERS 2002: 210). Zaměření na studium česko-německých vztahů ještě ve svých závěrečných ročnících částečně nahrazuje Slavische Rundschau (EHLERS 2002: 216). Na podzim 1938 a později po zrrízení Protektorátu se Bittner ještě neúspěšně pokoušel obnovit vydávání Germanoslavica, nyní již s propagandistickým proněmeckým smyslem (KONRÁD 2011: 190). Spolu s rektorem pražské německé univerzity Wilhelmem Saurem usilovali o využití Slovanského ústavu a dalších slavistických institucí pro německé účely. Bittner byl v lednu 1941 dosazen Saurem do vedení Slovanského ústavu, jelikož ale v letním semestru začátkem roku odešel na Poznaňskou univerzitu, nahradil jej v září Gesemann (KONRÁD 2011: 228-229). Časopis Germanoslavica byl obnoven až v roce 1994 a je dodnes vydáván Slovanským ústavem Akademie věd České republiky v nakladatelství Euroslavica. 


\section{Prager Rundschau}

Dvouměsíčník Prager Rundschau (1931-1939), vydávaný nakladatelstvím Orbis společně s berlínským nakladatelstvím Walther Rothschild, rovněž koresponduje s programem česko-německé vzájemnosti a spolupráce výše uvedených periodik a nejvíce se podobá také Orbisem vydávaným novinám Prager Presse. Je ale otevřeněji prostátní: Představuje a vysvětluje aktivity vlády Československé republiky, informuje o vývoji české politiky a hospodářství. Jeho hlavní redaktor, historik Kamil Krofta, byl v době vydávání Prager Rundschau vysokým úředníkem československého ministerstva zahraničí a v letech 1936-1938 dokonce ministrem zahraničí. Př́ležitostně do Prager Rundschau přispěli Milan Hodža nebo Edvard Beneš. Výkonným redaktorem Prager Rundschau byl Antonín Hartl, od roku 1938 člen PLK, a sekretářem Mágr. Mezi spolupracovníky Prager Rundschau patřili profesoři Univerzity Karlovy jako Jan Wolf či Antonín Boháč, vědci jako Matija Murko, publicisté jako Ferdinand Peroutka. Články o divadle zde pravidelně až do roku 1936 přispíval Otokar Fischer, literatuře se věnoval Miroslav Rutte. Prager Rundschau strukturou připomíná Germanoslavica nebo Slavische Rundschau. Z povahy svého zaměření publikoval v Prager Rundschau redaktor Hartl pravidelně články o Slovensku a Podkarpatské Rusi (viz HARTL 1931, 1937b). Mimo jiné zde vyšla Bogatyrevova studie „Úkoly etnografa na Podkarpatské Rusi a Východním Slovensku“ (BOGATYREV 1933), ve které Bogatyrev rozvádí nebo předznamenává myšlenky formulované v jiných periodicích. Stejně jako ve Slově a slovesnosti zde Mukařovský publikoval nekrolog F. X. Šaldy (MUKAŘOVSKÝ 1937a). Frank Wollman v Prager Rundschau zveřejnil svou kritiku Bittnerovy knihy Deutsche und Tschechen (WOLLMAN 1937) a Silberstein rozsáhlou studii rozvíjení Masarykova odkazu v české filosofii (SILBERSTEIN 1938). O kroužku zde psal Mágr (MÁGR 1932d) a v souvislosti s moderní jazykovědou Trnka (TRNKA 1932) a Murko (MURKO 1931).

Cíl představit novou republiku německému a německojazyčnému čtenářstvu a podpořit česko-slovensko-německou kulturní výměnu zdůraznil Krofta v úvodním textu prvního čísla. Připomněl tradici německojazyčných revue, které vycházely v Praze před první světovou válkou a zdůraznil potřebu informovat o politickém, hospodářském a společenském životě na Podkarpatské Rusi a také Mad’arů žijících v Československu. Autorům Prager Rundschau tedy šlo - podobně jako u Slavische Rundschau a Germanoslavica - o vzájemnou vědeckou spolupráci a mírumilovné soužití mezi národy (KROFTA 1931). Po větších studiích následují menší zprávy - v tomto případě přehled vnitřní a zahraniční politiky - a po nich kronika. Prager Rundschau bylo po nacistickém převzetí moci v Německu zakázané (EHLERS 1997: 183). Poslední číslo vyšlo 15. ledna 1939, kdy redakce ukončila činnost.

Ehlers ve své habilitaci (EHLERS 2005) o německé recepci strukturalismu v letech 1926-1946 ukázal, že strukturalistické podněty „Pražské školy“ byly v německém prostředí přijímány více, než se předpokládalo. Kroužek, jehož publikace v Německu úspěšně distribuovalo nakladatelství Harrassowicz (NEKULA 2007: 48), rozesílal mimo jiné 
díky finanční podpoře československých ministerstev školství a zahraničí své publikace do ciziny. Nemám sice přehled o dobové čtenosti Germanoslavica nebo Slavische Rundschau v Německu nebo Rakousku, Barbara Köpplová však upozorňuje na bojkot Prager Presse sudetskými Němci (KÖPPLOVÁ 1986: 16) a Ehlers na zákaz Prager Rundschau v Německu po převzetí moci nacisty (EHLERS 1997: 183). Přesto se domnívám, že výše popsaná periodika zprostředkovávala a udržovala kontakt s domácím a zahraničním německým prostředím či alespoň se zahraničními slavisty a germanisty. Rovněž dokumentují podobu spolupráce vědců různého původu a profesního zaměření. Proto tato periodika, tolik spojená s meziválečným Československem a jeho proměnami, považuji za významný pramen poznání meziválečné vědecké kultury a kulturní politiky.

\section{Bibliografie}

BERNÁTEK, Martin. 2014. The Prague Linguistic Circle and the Prager Presse: a remark on the science in interwar Czechoslovakia. Theatralia 17 (2014): 2: 175-187.

BOGATYREV, Petr a Roman JAKOBSON. 1929. Literatur und Folklore. Dichtung und Welt 36. Beilage zur Prager Presse 9 (8. 9. 1929): 245: I-III.

BOGATYREV, Petr. 1930a. Ethnographische Praxis: Erfahrungen eines Feldethnographien in Rußland und Karpathorußland. Slavische Rundschau 2 (Mai 1930): 5: 331-337.

BOGATYREV, Petr. 1930b. Lévy-Bruhl und die Ethnographie der europäischen Völker. Prager Presse 10 (8. 11. 1930): 306: 6.

BOGATYREV, Petr. 1932. Der Weihnachstbaum in der Ost-Slovakei. Germanoslavica 2 (Dezember 1932): 2: 254-258.

BOGATYREV, Petr. 1933. Aufgaben des Ethnographen in Karpathorussland und in der Ostslovakei. Prager Rundschau 3 (20. 3. 1933): 2: 114-130.

BOGATYREV, Petr. 1938. Zur Frage der gemeinsamen Kunstgriffe im alttschechischen und im volkstümlichen Theater. Slavische Rundschau 10 (1938): 6: 154-161.

BOGARYTEV, Petr. 1971. Lévy-Bruhl a etnografie evropských národů [Lévy-Bruhl and the Ethnography of European Nations]. Týž. Jaroslav Kolár (ed.). Souvislosti tvorby [Context of Creations]. Praha: Odeon, 1971: 55-57.

BOGATYREV, Petr G. 2011. Funktional-strukturale Ethnographie in Europa: Texte aus den 1920er und 1930er Jahren zu Brauchtum, Folklore, Theater und Film. Klaas-Hinrich Ehlers, Marek Nekula (edd.). Winter: Heidelberg, 2011.

ČERMÁK, Petr, Claudio POETA a Jan ČERMÁK. 2012. Pražský lingvistický kroužek v dokumentech [Prague Linguistic Circle in Documents]. Praha: Academia, 2012.

ČYŽEVS‘KYJ, Dmytro. 1937. Puškin und die Romantik. Germanoslavica 5 (24. 10. 1937): 1-2: $1-32$.

DEJMEK, Jindřich. 2012. Diplomacie Československa: Díl 1. Nástin dějin ministerstva zahraničních věcí a diplomacie (1918-1992) [Czechoslovak Diplomacy: An outline of the history of the Czechoslovak Ministry of Foreign Affairs]. Praha: Academia, 2012.

Der altpolnische und der alttschechische Vers. 1937. Prager Presse 17 (15. 10. 1937): 284: 8. 
Der „Pražský linguistický kroužek“... [The Prague Linguistic Circle...]. 1932. Prager Presse 12 (1. 11. 1932): 298: 8.

Die slavische Wechselseitigkeit in Vergangenheit und Gegenwart. 1926. Prager Presse 6 (1. 4. 1926): 91: 6 .

Die Sprachlaute im Lichte der Psychologie. 1932. Prager Presse 12 (23. 3. 1932): 83: 10.

EHLERS, Klaas-Hinrich. 1997. Die Slavische Rundschau 1929-1940. Brucken: Germanistisches Jahrbuch Tschechien-Slowakei 5 (1997): 149-204.

EHLERS, Klaas-Hinrich. 2001. Die Gründung der Germanoslavica. Germanoslavica: Zeitschrift für germano-slawische Studien. Praha: Slovanský ústav 8 (13) (2001): 1: 83-103.

EHLERS, Klaas-Hinrich. 2002. Agonie und Nachleben einer deutsch-tschechischen Zeitschrift: Dokumente zum Ende der Germanoslavica aus den Jahren 1932 bis 1942. Brücken. Germanistisches Jahrbuch Tschechien-Slowakei 8 (2002): 179-222.

EHLERS, Klaas-Hinrich. 2003. Prager Deutsche im Prager Zirkel. Ein Überblick. In Marek Nekula (ed.) Prager strukturalismus: Methodologische Grundlagen. Heidelberg: Winter, 2003: 49-77.

EHLERS, Klaas-Hinrich. 2005. Strukturalismus in der deutschen Sprachwissenschaft: die Rezeption der Prager Schule zwischen 1926-1946. Berlin: de Gruyter, 2005.

EHLERS, Klaas-Hinrich. 2011. Petr G. Bogatyrev: Leben und Werk im wissenschaftlichen Kontext. In Peter G. Bogatyrev. Funktional-strukturale Ethnographie in Europa: Texte aus den 1920er und 1930er Jahren zu Brauchtum, Folklore, Theater und Film. Klaas-Hinrich Ehlers a Marek Nekula (edd.). Winter: Heidelberg, 2011: 19-53.

Eine neue slavistische Revue: Im Dienst der europäischen Kulturgemeinschaft. 1928. Dichtung und Welt 15. Beilage zur Prager Presse 8 (8. 4. 1928): 99: VIII.

Ein „Ethnographischer Zirkel“. 1930. Slavische Rundschau 2 (Januar 1930): 1: 71.

EISNER, Paul. 1932. Sprachkultur und Sprachwissenschaft. Literaturzeitung 18. Beilage zur Prager Presse 12 (28. 10. 1932): 295: III.

(P. E.) [EISNER, Pavel]. 1936. Blut und Leben. Prager Presse 16 (20. 6. 1936): 169: 8.

EISNER, Pavel. 1937. Překladatel A. St. Mágr... [Translator A. St. Mágr]. In Antonín Hartl (ed.). A. St. Mágrovi k padesátým narozeninám 6. dubna 1937 [In Honour of A. St. Mágr's $50^{\text {th }}$ Jubilee, 6 Apr. 1937]. Praha: Kruh přátel v Praze, 1937.

(P. E.) [EISNER, Pavel]. 1938. Nikolaj Trubetzkoy. Prager Presse 18 (30. 6. 1938): 165: 8.

FISCHER, Otokar. 1929. Deutsche Slavistik und tschechische Germanistik. Prager Presse 9 (29. 3. 1929): 88: 7.

FISCHER, Otokar. 1931-1932. Zur Ideengeschichte des „Konrad Wallenrod“. Germanoslavica 1 (1931-1932): 1: 55-76.

GESEMANN, Gerhard. 1929. Eins ist not. Slavische Rundschau 1 (1929): 8: 623-629.

GESEMANN, Gerhard. 1930. Rückblick und Ausblick. Slavische Rundschau 2 (1930): 1: 1-7.

HARTL, Antonín. 1931. Die literarische Renaissance der Karpathoruthenen. Prager Rundschau 1 (28. 10. 1931): 6: 558-565.

HARTL, Antonín (ed.). 1937a. A. St. Mágrovi k padesátým narozeninám 6. dubna 1937 [In Honour of A. St. Mágr's 50 $0^{\text {th }}$ Jubilee, 6 Apr. 1937]. Praha: Kruh přátel v Praze, 1937.

HARTL, Antonín. 1937b. Das heutige literarische Schaffen in Karpathorussland. Prager Rundschau 7 (28. 1. 1937): 1: 39-46. 
HAUSER, Jakub. 2009. Eurasijstvi a skupina „Skify“ 1930-1933 [Eurasianism and the "Skify” Group 1930-1933]. Praha: Filozofická fakulta Univerzity Karlovy v Praze, 2009. Diplomová práce [Diploma Thesis].

HAVRÁNEK, Bohuslav. 1936. Zehn Jahre Prager linguistischer Zirkel. Slavische Rundschau 8 (1936): 5: 315-320.

HAVRÁNKOVÁ, Marie a Vladimír PETKEVIČ (edd.). 2014. Pražská škola v korespondenci: dopisy $z$ let 1924-1989 [The Prague School in Letters (1924-1989)]. Praha: Karolinum, 2014.

HERRMANN, Konrad. 2015. Leopold Silberstein: Slawist und Philosoph. Berlin: Be.bra, 2015.

(Hkt.) [HEXTER, Maxim]. 1935. Das Musikwerk als Zeichen. Prager Presse 15 (16. 1. 1935): 15: 7. HORÁK, Jiří. 1937. A. St. Mágr... . In Antonín Hartl (ed.). A. St. Mágrovi k padesátým narozeninám 6. dubna 1937 [In honour of A. St. Mágr's $50^{\text {th }}$ jubilee, 6 Apr. 1937]. Praha: Kruh přátel v Praze, 1937.

HOSKOVEC, Tomáš. 2010. Klub a Kroužek: Úvahy o dynamice české filologie [The Club and the Circle: Reflections on the Dynamism of Czech philology]. In Moderni filologie na prahu tretího tisícileti [Modern philology at the beginning of the third milénium]. XXIII ročenka Kruhu moderních filologů. Praha: Kruh moderních filologů, 2010: 26-40.

JAKOBSON, Roman. 1929. Romantické všeslovanství - nová slavistika [Romantic Panslavism New Slavic Studies]. Čin [The Act] 1 (31. 10. 1929): 1: 10-12.

JAKOBSON, Roman. 1931a. Das Genfer Linguistenkongreß. Prager Presse 11 (13. 9. 1931): 248: $8-9$.

JAKOBSON, Roman. 1931b. Prof. Dr. Friedrich Slotty. Prager Presse 11 (18. 10. 1931): 282: 8.

rn [JAKOBSON, Roman]. 1932a. Die Personennamen bei Dostojevskij. Prager Presse 12 (10. 12. 1932): 337: 7.

JAKOBSON, Roman. 1932b. Prof. Vilém Mathesius. Prager Presse 12 (3. 8. 1932): 211: 6.

JAKOBSON, Roman. 1933. Ukázky z chystané monografie o šlágrech V \& W [Excerpts From the Planned Monograph on Voskovec \& Werich's Hits]. In Tucet melodii z Osvobozeného divadla [Dozen Melodies From the Liberated Theatre]. Praha: Hudební matice Umělecké besedy, 1933.

(rn) [JAKOBSON, Roman]. 1935. Viggo Brøndal... Prager Presse 15 (17. 4. 1935): 106: 6.

JAKOBSON, Roman. 1936. Ein Grundwerk zur tschechoslovakischen Sprachgeschichte. Prager Presse 16 (5. 1. 1936): 4: 10.

JAKOBSON. Roman. 1937a. Dopis Jiřímu Voskovcovi a Janu Werichovi o noetice a semantice švandy [Letter to Jiří Voskovec and Jan Werich on Noetics and Semantics of Fun]. In Josef Träger (ed.). Deset let osvobozeného divadla 1927-1937 [Ten Years of the Liberated Theatre 1927-1937]. Praha: Fr. Borový, 1937: 27-34.

JAKOBSON, Roman. 1937b. Olaf Broch - 70 Jahre. Prager Prese 17 (4. 8. 1937): 211: 6.

(R. J.) [JAKOBSON, Roman]. 1937c. Prof. L. Hjelmslev in Prag. Prager Presse 17 (22. 10. 1937): 291: 8.

JAKOBSON, Roman. 1937d. Věda a noviny v pojetí Mágrově [Mágr’s Approach to Science and Journalism]. Lidové noviny [The People's Newspaper] 45 (6. 4. 1937): 173: 9.

(R. Jn) [JAKOBSON, Roman]. 1938. Professor František Trávníček 50 Jahre. Prager Presse 18 (17. 8. 1938): 205: 8.

JAKOBSON, Roman (ed.). 1975. N. S. Trubetzkoy`s Letters and notes. The Hague: Mouton, 1975. 
JAKOBSON, Roman. 2013. Selected Writings. Volume IX. Jindřich Toman (ed.) ve spolupráci s Stephen Ruby. Berlin, Boston: De Gruyter Mouton, 2013.

KARCEVSKIJ, Sergej. 1930. Roman Jakobson. Prager Presse 10 (19. 3. 1930): 78: 8.

KONRÁD, Ota. 2011. Dějepisectví, germanistika a slavistika na Německé univerzitě v Praze 1918-1945

[Historiography, German and Slavic Studies at the German University in Prague 1918-1945]. Praha: Karolinum, 2011.

Ko. [KOŽEŠNÍK, Karel]. 1934. Šklovskij in kritischem Licht. Prager Presse 14 (14. 3. 1934): $72: 6$. KÖPPLOVÁ, Barbara. 1986. Prager Presse - Založeni listu a jeho kulturně politická úloha v letech 1921-1925 [Prager Presse - the founding of the newspaper and its role in cultural policy in 1921-1925]. Praha: Československá akademie věd v Praze, 1986. Autoreferát disertace [Doctoral dissertation thesis statement].

[KROFTA, Kamil?]. 1931. Geleitwort. Prager Rundschau 1 (15: 2. 1931): 1: 1-2.

LIEWEHR, Ferdinand (ed.). 1929. Slawistische Studien: Franz Spina zum sechzigsten Geburtstag von seinen Schülern. Reichenberg: Gebrüder Stiepel, 1929.

MATHESIUS, Vilém. 1925. Kulturni aktivismus: anglické paralely k českému životu [Cultural Activism: English Parallels to Czech Life]. Praha: Gustav Voleský, 1925.

MATHESIUS, Vilém. 1933. Probleme der čechischen Sprachkultur. Slavische Rundschau 5 (20. 2. 1933): 2: 70-85.

Mgr. [MÁGR, Antonín Stanislav]. 1929a. Germanoslavica. Prager Presse 9 (26. 11. 1929): 321: 8.

Mgr. [MÁGR, Antonín Stanislav]. 1929b. In Namen Herders. Prager Presse 9 (26. 10. 1929): 292: 1 .

[MÁGR, Antonín Stanislav]. 1929c. Nachklänge zum Slavisten-Kongreß. Prager Presse 9 (2. 11. 1929): 297: 6.

Mgr. [MÁGR, Antonín Stanislav]. 1932a. Die Stabilität in der Schriftsprache. Prager Presse 12 (13. 1. 1932): 13: 8.

Mgr. [MÁGR, Antonín Stanislav]. 1932b. Die tschechische Schriftsprache und Kultur der Sprache. Prager Presse 12 (10. 1. 1932): 10: 11.

Mgr. [MÁGR, Antonín Stanislav]. 1932c. Dichterische Sprache und Schriftsprache. Prager Presse 12 (11. 2. 1932): 42: 8.

Mgr. [MÁGR, Antonín Stanislav]. 1932d. Pražský linguistický kroužek [The Prague Linguistic Circle]. Prager Rundschau 2 (15. 12. 1932): 6: 571-572.

Mgr. [MÁGR, Antonín Stanislav]. 1932e. Sprache und Kultur. Prager Presse 12 (29. 1. 1932): 29: 8.

Mgr. [MÁGR, Antonín Stanislav]. 1932f. Ueber die Kultur der lautlichen Seite der tschechischen Sprache. Prager Presse 12 (10. 2. 1932): 41: 8.

Mgr [MÁGR, Antonín Stanislav]. 1932g. Zur Kritik des Purismus. Prager Presse 12 (28. 1. 1932): 28: 8.

Mgr. [MÁGR, Antonín Stanislav]. 1932h. Zur Kultur der Sprache. Prager Presse 12 (27. 1. 1932): 27: 8.

MÁGR, Antonín Stanislav. 1936. Měl jsem př́ležitost... [I Had the Opportunity... ]. Slovo a slovesnost [The Word and The Verbal Art] 2 (1936): 2: 132.

MÁGR, Antonín Stanislav. 1947. Kulturni Slavica v Prager Presse: In memoriam Arne Laurina [Slavic Culture Subjects in Prager Presse: In Memoriam Arne Laurin]. 2. vydání. Praha: Orbis, 1947. 
MATHESIUS, Vilém. 1930. Die Internationale Phonologische Konferenz in Prag. 18.-21. Dezember 1930. Prager Presse 10 (31. 12. 1930): 357: 8.

Moderne Sprachwissenschaft und Slavistik: Diskussionsthesen für den Kongreß der slavischen Philologen in Prag. 1929. Prager Presse 9 (1. 10. 1929): 267: 8.

MUKǍ̌OVSKÝ, Jan. 1937a. F. X. Šalda. Prager Rundschau 7 (20. 5. 1937): 3: 198-224.

MUKǍ̌OVSKÝ, Jan. 1937b. Je již osud věd... [The Destiny of Scholarship]. In Antonín Hartl (ed.). A. St. Mágrovi k padesátým narozeninám 6. dubna 1937 [In Honour of A. St. Mágr's 50 $0^{\text {th }}$ Jubilee, 6 Apr. 1937]. Praha: Kruh přátel v Praze, 1937.

MURKO, Matija. 1931. Der Ausbau der Slavistischen studien in der Tschechoslovakei. Prager Rundschau 1 (20. 8. 1931): 4: 332-348.

NEKULA, Marek. 2007. Strukturalismus in der deutschen Sprachwissenschaft. Slovo a slovesnost [The Word and The Verbal Art] 68 (2007): 1: 46-52.

RÁDL, Emanuel. 1931. Presse und Wissenschaft. Presse und Gesellschaft. Beilage zur Prager Presse 11: (12. 4. 1931): 100: 10.

RAUCHOVÁ, Jitka. 2009. Propagace, nebo protekce? Prager Presse a avantgardní divadlo [Promotion or Protection? Prager Presse and the Avant-Garde Theatre]. In Dagmar Blümlová (ed.). Čas optimismu a ctižádostivých naději: prezentace a reprezentace české vědy a kultury v pruním desetileti samostatného státu (1918-1929) [Time of Optimism and Ambitious Hopes: presentation and representation of the Czech science and culture in the first decade of the independent Czechoslovak state (1918-1929)]. České Budějovice: Jihočeské muzeum v Českých Budějovicích a Společnost pro kulturní dějiny, 2009: 209-215.

RIPPL, Eugen. 1936. K. Bittner: Deutsche und Tschechen: Zur Geistgeschichte des böhmischen Raumes. Germanoslavica 4 (24. 10. 1936): 3-4: 349-352.

ROUBÍK, František. 1947-1948. Německé plány se slovanskými ústavy v Praze za okupace [German Plans for Slavic Institutions in Prague During the Ocuppation]. Slavia 18 (1947-48): 3-4: 512-520.

SÉRIOT, Patrick. 2003. Struktura a celek: Intelektuálni počátky strukturalismu ve středni a východni Europě [Structure and the Whole: East, West and Non-Darwinian Biology in the Origins of Structural Linguistics]. Praha: Academia, 2003.

(L) [SILBERSTEIN, Leopold?]. 1935a. Die tschechische philosophische Terminologie der Gegenwart. Prager Presse 15 (5. 12. 1935): 329: 6.

(L. S.) [SILBERSTEIN, Leopold]. 1935b. Linguistik und Phänomenologie. Prager Presse 15 (22. 11. 1935): 316: 8.

(L. S.) [SILBERSTEN, Leopold]. 1935c. Über reistische Sprachbetrachtung in ihrem Verhältnisse zur Logistik und Phänomenologie... Prager Presse 15 (19. 12. 1935): 343: 10.

SILBERSTEIN, Leopold. 1938. Philosophisches Streben und Schaffen im Lande Masaryks. Prager Rundschau 8 (31. 1. 1938): 1: 13-29; 8 (10. 5. 1938): 2: 95-113.

SLÁDEK, Ondřej (ed.). 2014. Český strukturalismus v diskusi [Czech structuralism in discussion]. Brno: Host, 2014.

SLÁDEK, Ondřej. 2015. The Metamorphoses of Prague School Structural Poetics. München: LINCOM, 2015.

Slavische Rundschau: Werbeheft. 1929. Berlin - Leipzig - Prag: Walter de Gruyter [1929?]. Dostupné v Bibliotece Uniwersytecke w Warszawie, sg. 013493, 1 (1929?): 7-8 a dodatek. 
Slovo a slovesnost [The Word and the Verbal Art] [online]. 2011 [15. 7. 2015]. Praha: Ústav pro jazyk český Akademie věd České republiky, vvi. [30. 12. 2013]. Dostupné online: 〈http://sas. ujc.cas.cz>.

ŠTEFANOVÁ, Alena. 2009. Prager Presse, Arne Laurin a meziválečná Praha [Prager Presse, Arne Laurin, and the Interwar Prague]. České Budějovice: Historický ústav Filosofické fakulty Jihočeské univerzity, 2009. Diplomová práce [Master's thesis].

TRÁVNÍČEK, František. 1935. Spráuná česká výslownost [Proper Czech Pronounciation]. Brno: Zemské divadlo v Brně, 1935.

TRNKA, Bohumil. 1932. Die neue Linguistik und die tschechische Schriftsprache. Prager Rundschau 2 (15. 12. 1932): 6: 508-515.

TOMAN, Jindřich. 2011. Př́běh jednoho moderního projektu: Pražský lingvistický kroužek, 1926-1948

[The Magic of the Common Language: Jacobson, Mathesius, Trubetzkoy, and the Prague Linguistic Circle]. Praha: Karolinum, 2011.

VACHEK, Josef. 1966. The Linguistic School of Prague: An Introduction to its Theory and Practice. Bloomington \& London: Indiana University Press, 1966.

WIJK, Niklaas van. 1935. Eine slavisch-germanische syntaktische Parallele. Germanoslavica 3 (1935): 1-2: 19-31.

WOLLMAN, Frank. 1937. Zur vergleichenden slavischen Literaturwissenschaft. Prager Rundschau 7 (18. 12. 1937): 6: 412-432.

Zum Geleit. 1931. Germanoslavica 1 (1931): 1: 2.

Zum Ostnorwegischen. 1938. Prager Presse 18 (2. 6. 1938): 142: 8. 


\section{Summary}

\section{Partnership and Promotion: the Prague Lingvistic Circle and German Newspapers in the Interwar Czechoslovakia}

This volume aims at presenting several newspapers written in German, specifically the Prager Presse, Slavische Rundschau, Germanoslavica and Prager Rundschau, that were established in the interwar Czechoslovak Republic under the cooperation of members of both the German and Czech ethnic groups. The relation of these newspapers towards the Prague Linguistic Circle, which was covered especially by the Prager Presse, is discussed in detail in the main study, as well as the activities of the German members of the Circle who contributed to the given periodicals on regular basis, and of Antonín Stanislav Mágr, a paragon of scientific journalism as the members of the Circle called him. The author argues that the publishing and other activities of the newspapers and the Circle not only represent one step on the path towards the institution of modern scholarship, but also a means of its promotion and popularization. The study is supplemented by an annotated bibliography of the articles on the activities of the Circle in the Prager Presse, Slavische Rundschau, Germanoslavica and Prager Rundschau.

\section{Klíčová slova}

Pražský lingvistický kroužek, Pražská škola, strukturalismus, lingvistika, slavistika, germanistika, Německá univerzita v Praze, Československá republika, sudetští Němci, německý politický aktivismus, spolupráce, tisk, vědecká žurnalistika, popularizace vědy, Prager Presse, Slavische Rundschau, Germanoslavica, Prager Rundschau, Antonín Stanislav Mágr

\section{Keywords}

Prague linguistic circle, Prague School, structuralism, linguistics, Slavic studies, German studies, German university in Prague, First Czechoslovak Republic, Sudeten Germans, Sudeten German political activism, collaboration, press, science journalism, science popularisation, Prager Presse, Slavische Rundschau, Germanoslavica, Prager Rundschau, Antonín Stanislav Mágr

\section{DOI: 10.5817/TY2016-S-1}

Martin Bernátek (bernatek@mail.muni.cz) se zabývá vztahem divadla, architektury a médií a dějinami divadelních studií zejména v první polovině 20. století. Studoval dějiny divadla a kultury a teorii interaktivních médií na Masarykově univerzitě (CZ), Laponské univerzitě (FI) a Varšavské univerzitě (PL). Od roku 2013 je odborným neakademickým pracovníkem Katedry divadelních studií MU.

Martin Bernátek (bernatek@mail.muni.cz) is researcher in the field of theatre architecture, theatre and media relations and theatre studies history, particularly in the first half of the $20^{\text {th }}$ century. He studied history of performance and culture and interactive media theory at Masaryk University (CZ), University of Lapland (FI) and University of Warsaw (PL). Since 2013 works as a non-academic specialist at the Department of Theatre studies, Masaryk University (Brno, CZ). 


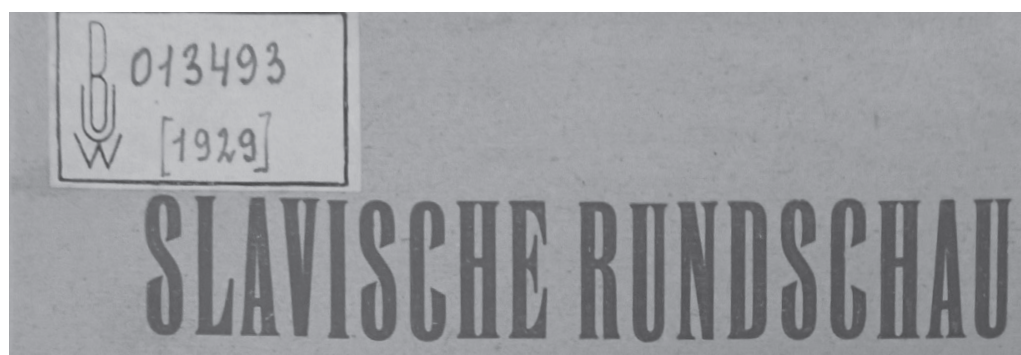

\title{
Berichtende und kritische Zeitschrift
}

fiir das

\section{geistige Leben der slavischen Völker}

\author{
Herausgegeben von
}

FRANZ SPINA und GERHARD GESEMANN

Prag

\section{Werbeheft}

Die Zeitschrift erscheint vom Januar 1929 an

Umfang eines Heftes ca. 80 Seiten mit Abbildungen

Verlag Walter de Gruyter \& Co.

Berlin-Leipzig-Prag

Propagační brožura revue Slavische Rundschau (1929?) uložená ve Varšavské univerzitní knihovně. V avizovaném seznamu spolupracovníků byli uvedeni mimo jiné Roman Ingarden,

Gustav Špet, Boris Tomaševskij, Hubert Ripka, Ilja Ehrenburg nebo Karel Teige. 
vorwiegend nichtästhetische Funktion erfült, sondern auch bei anderen objekten zu verfolgen ist, die bei den höheren Klassen eine ausgesprochene asthetische Funktion erfüllen.

Ferner wäre Material darüber zu beschaffen, ob die Kunst der höheren Klassen während der verschiedenen sozialen und religiösen Umwälzungen zusammen mit dem Ubergang anderer Lebensformen „,en bloc" in das Volk hinabsteigt oder nur schichtweise, unabhängig vom Übergang anderer Formen der höheren Klassen zum Dorfe, unabhängig z. B. von der Anpassung der ländlichen sozialen Struktur an die Stadt. In diesem Zusammenhang müßte auch die Frage beleuchtet werden, in welches Verhältnis die ins Dorf eindringenden Elemente der Stadtkunst zu der Dorfkunst treten, deren Ablösung sie besorgen.

Ich bin mir vollkommen darüber klar, daß die hier umrissenen aktuellen Probleme nur von erfahrenen und vorsichtigen Sammlern gelöst werden können. Auf jeden Fall aber muß an ihrer Lösung gearbeitet werden, und dazu müssen erfahrene Sammler herangezogen und weniger erfahrene vorbereitet werden. Übrigens gibt es eine dringende Aufgabe, an deren Lösung auch wenig vorbereitete lokale Sammler mitwirken können: das Sammeln von Material zur Kartographierung der einzelnen ethnographischen Erscheinungen und Tatsachen. Der Sammler braucht hier nur festzustellen, ob die angegebene ethnographische Tatsache existiert.

\title{
Deutsch-slavische Wissenschaft einst, jetzt und in Zukunft
}

\section{Dargestellt an einem Kapitel deutscher Rußlandkunde}

\author{
Von P. Savickij
}

\begin{abstract}
Der folgende Artikel ist von grundsätzlicher kulturpolitischer Bedeutung. Er ist zwar auf geographischem (im weitesten Sinne) Material aufgebaut, seine Schlußfolgerungen beziehen sich hier auf die Wissenschaften des geographischen Kreises, doch steht es außer Zweifel, daß bei entsprechender Durcharbeitung auch die anderen Zweige der deutschrussischen wissenschaftlichen Bezichungen ein ähnliches Bild aufweisen wärden. Die Redaktion.
\end{abstract}

\begin{abstract}
Die Gesehichte der russischen Geographie im 18. bis 19. Jh. ist durch die engsto russisch-deutsche wissenschaftliche Zusammenarbeit gekennzeichnet. Freilich fallt der Beginn der geographischen Regsamkcit
\end{abstract}

Začátek studie Petra Savického „Německo-slovanská věda dříve, nyní a v budoucnosti“ otištěné v 5. čísle 2. ročníku Slavische Rundschau (květen 1930). Redakce upozorňuje na zásadní kulturněpolitický význam Savického textu. Článku předchází stat’ „Etnografická praxe“ Petra Bogatyreva, kde popsal zkušenosti s terénním výzkumem na Podkarpatské Rusi. 


$$
\text { Jahrgang I. 1931-1932. Heft } 3 .
$$

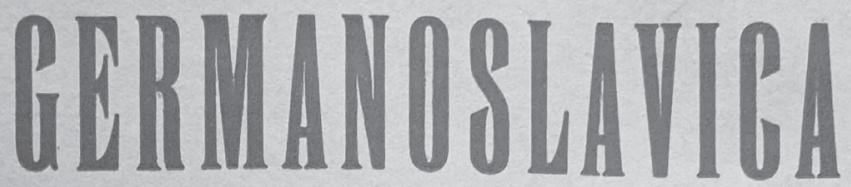

\title{
Vierteljahrsschrift für die Erforschung der germanisch-slavischen Kulturbeziehungen
}

Im Auftrage des Slavischen Institutes und der

Deutschen Gesellschaft für slavistische Forschung in Prag

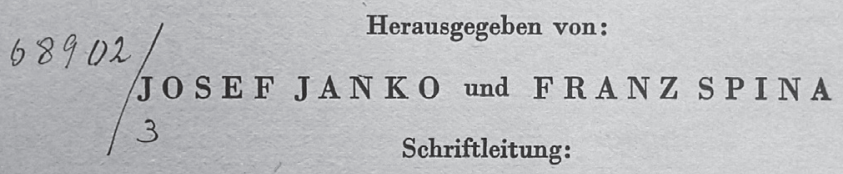

Schriftleitung:

KONRAD BITTNER - VOJTËCH JIRAT

\section{GOETHEHEFT}

\author{
VER L A G R U D O L F M. R O H R E R \\ B R U N N P RA G L E I P ZI G - W I E N
}

Obálka zvláštního, 3. čísla 1. ročníku čtvrtletníku pro výzkum německo-slovanských kulturních vztahů Germanoslavica, které vyšlo v červnu 1932 u přiležitosti stého výročí úmrtí J. W. Goetha.

Do čísla přispěli např. Otokar Fischer, Alfréd Bém, Vojtěch Jirát nebo Johannes Urzidil. Druhý „Goethovský sešit“ vyšel jako 1. číslo druhého ročníku. 


\section{\begin{tabular}{l} 
2. Oktober 1932 DICHTUNG UND WELT, BEILAGE ZUR ,PRAGER PRESSE" . \\
\hline
\end{tabular} LITERATURZEITUNG D}

Dix ans après

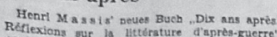
(Cablers de la Quinxaine, Pario 1032) Hefert

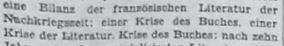

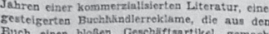
Buch erten blobes Ceschuftsartikel gennem
hat, ach der Vebersehwemmung des Bucherhat, aheh der Veberschwemmung des Bucher
marktes durch elne Unmasse von Novith

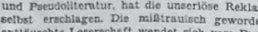

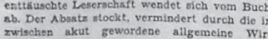

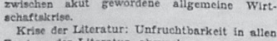

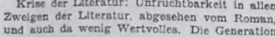

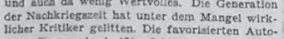

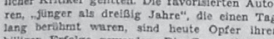

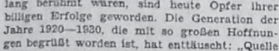
gen begrase worden ist, hat enttasuacht: : Quelli
oeurre, capable dexercer une infiuence, a-t-elle

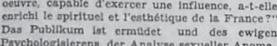

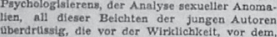

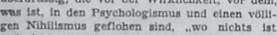
und nichts exiettert". Das Ergebonis: cin doppel-

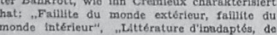

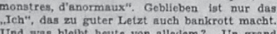

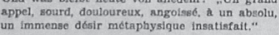
Matisson Buch ist bezelchnend, denn einen
nhalilichen Ton kaann man auch in anderen Stim-

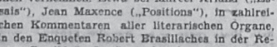

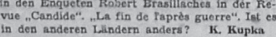

Slovenische Lebensläufe Ale die vernchledenen Volker nach dem Kriege
daran gingen, sich in den von Grund aua verkinderten Verhiltnissen zureectzurinden, sich in
itren manchmal erneuerten, vergroberten oder
verringerten Stantswescen einzurichten. sich in der neuen Welt $z u$ orientieren, mitunter such
die Vergangenhelt zu revilieren, oder die neuen

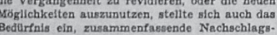
Bedurfnis ein, zunammentasesende. Nechechinga-
werke, neue Inventare des Wissens der Zelt im

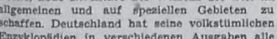

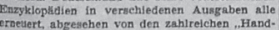
wortterbuluchern", dio eline typischo Form der H-

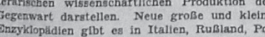

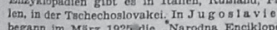

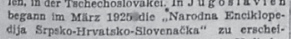

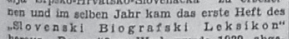

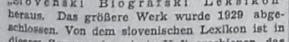

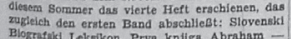

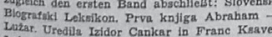

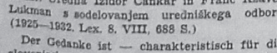

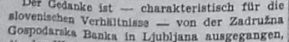

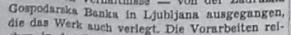

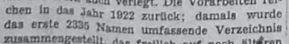

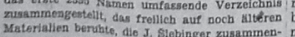

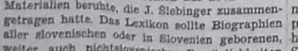

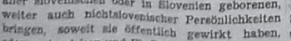

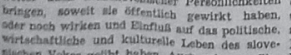

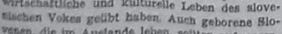

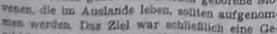

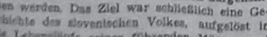

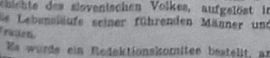

\section{Ostslavische Märchen}

Das ostslavische, hauptsăchlich das groß-|Reihe Fragen behandelt, die zwar von rus. russische Märchen ist seiner Form nach eincs
der interessantesten Forschern bereits gestreift worden

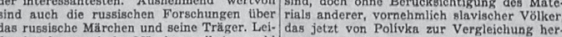

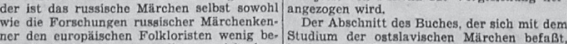
ner den europhilischen Folkloristen wenig ber
kannt. Rtudium der ostalavischen Matirchen befaBt,

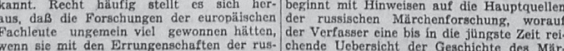

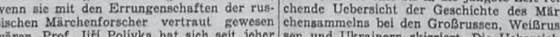

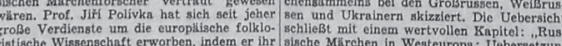

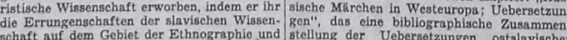

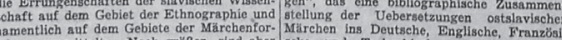

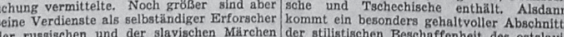

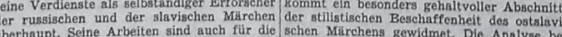

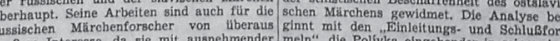

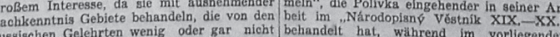

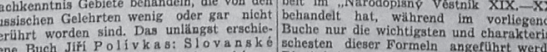

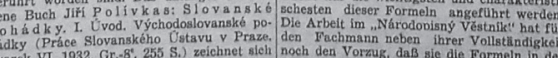

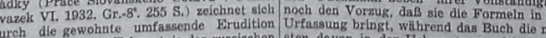
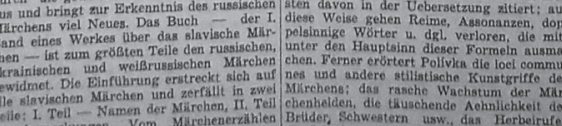

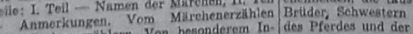

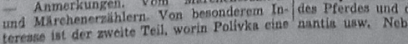

Titulní stránka nedělní přílohy Prager Presse Literaturzeitung z 2. října 1932 s recenzí Petra Bogatyreva Slovanských pohádek Jiřího Polívky a článkem o vydání románu Konec Civilizace Aldouxe Huxleyho od spolupracovníka PLK Sergeje Hessena. 


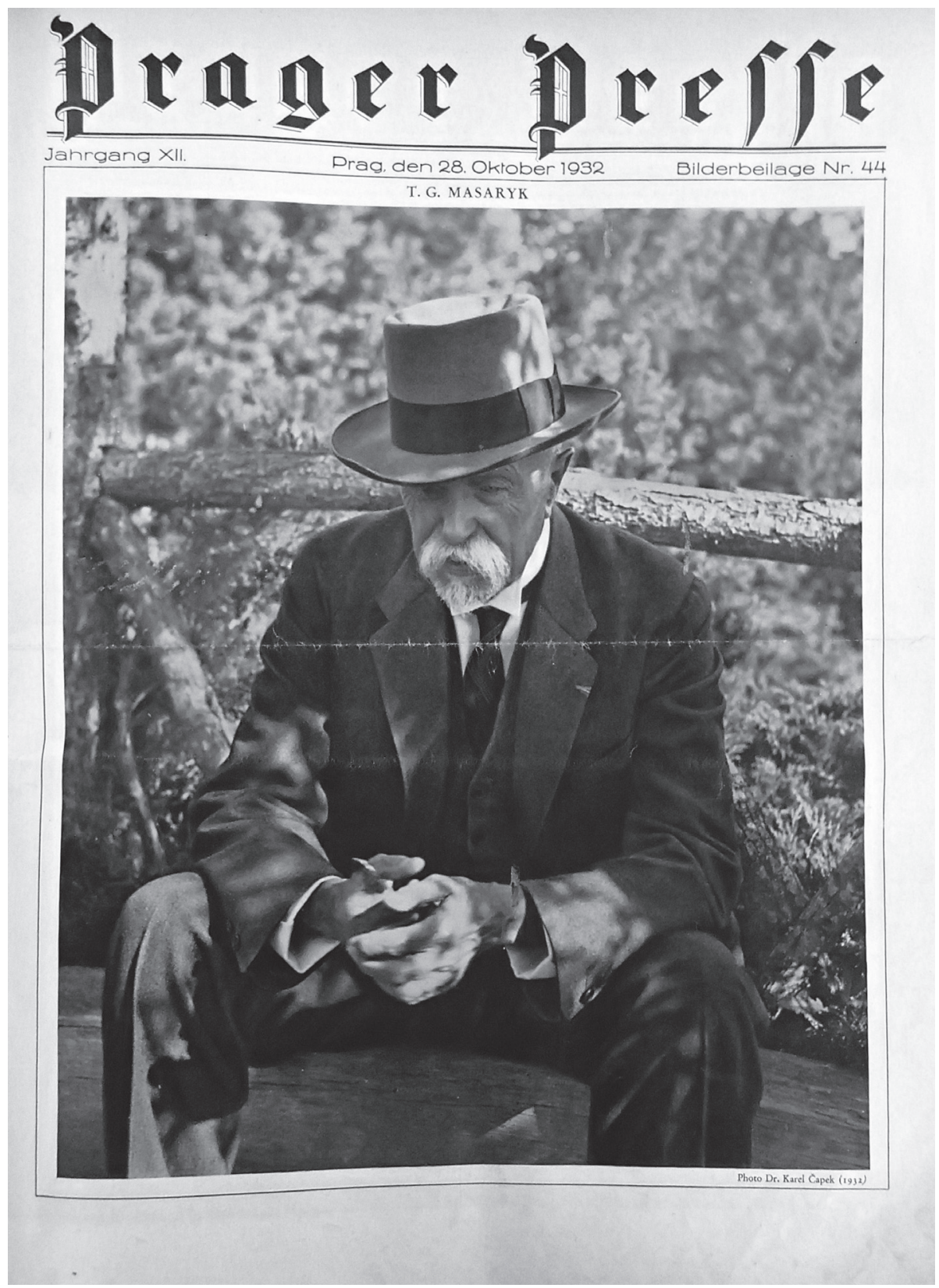

Obálka obrazové přílohy deníku Prager Presse s iniciátorem novin prezidentem T. G. Masarykem, vydaná jako součást oslav 14. výročí vzniku ČSR 28. října 1932. 


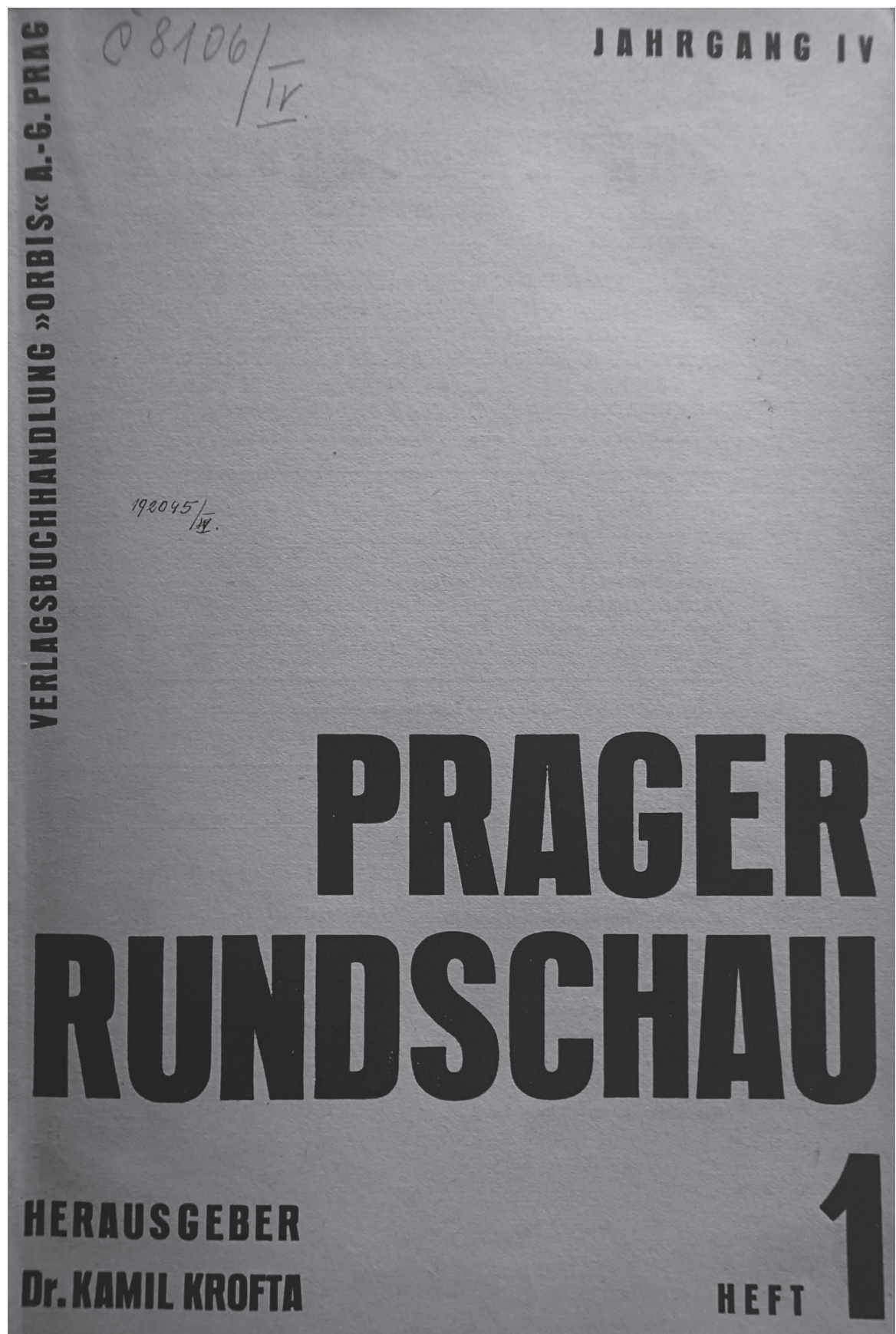

Obálka revue Prager Rundschau (1934). 


\section{Die Internationale des Geistes Der IX. Philosophen-Kongreß in Paris}

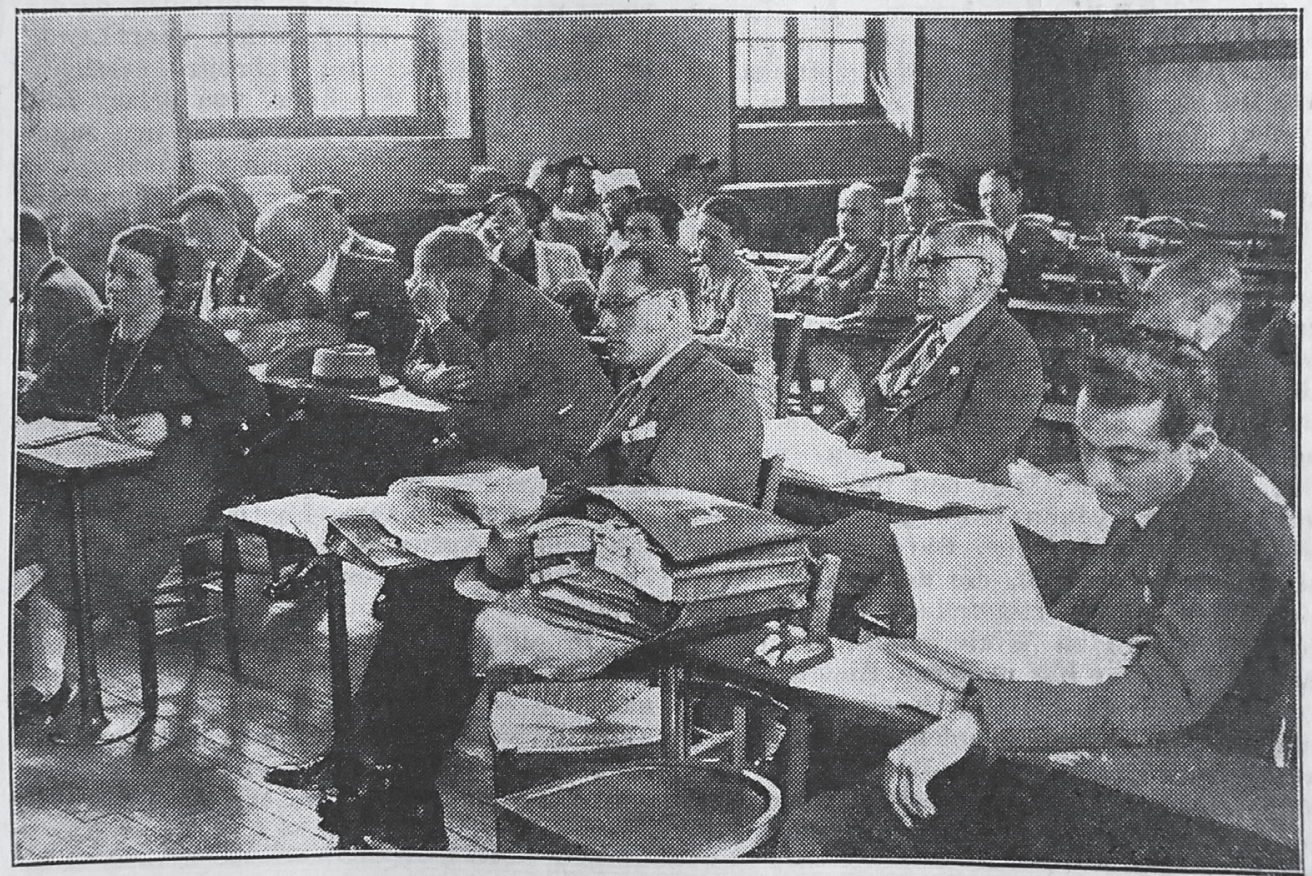

Sonder-Sektionssitzung des "Cercle philosophique de Prague" auf dem Pariser Philosophen-Kongreß

Leopold Silberstein v Prager Presse (8. 8. 1937) psal o mezinárodním sjezdu filozofů v Pařŕži v srpnu 1937. Na fotografii je zachyceno samostatné zasedání Pražského lingvistického kroužku, kterého se účastnili např. Emil Utitz, Jan Patočka, J. B. Kozák, Ludwig Landgrebe, Oskar Kraus, Silberstein (vpředu, první zprava) nebo Jan Mukařovský (vzadu, třetí zprava). 